\title{
ISOTOPIC MONITORING OF STEAM INJECTION USED TO STIMULATE PRODUCTION IN HEAVY OIL FIELDS IN THE POTIGUAR BASIN, BRAZIL
}

\author{
Danilo Ribeiro de Sá Teles ${ }^{1}$, Antônio Expedito Gomes de Azevedo², Alexandre Barreto Costa², \\ Maria do Rosário Zucchi², Alexandre de Andrade Ferreira ${ }^{3}$, Eugênio Vaz dos Santos Neto ${ }^{4}$, \\ Tárcio Henrique Ribeiro ${ }^{5}$ and Renato Carlos Vieira Santiago ${ }^{2}$
}

\begin{abstract}
The Alto do Rodrigues, Estreito and Salina Cristal, Potiguar Basin oil fields, Brazil, produce heavy oils which are derived from distinct production intervals. Steam injection is used to stimulate production, with the steam generated using water transferred by pipe from the Açu River. This work investigates the physicochemical and isotopic characteristics of the surface waters of the region, the water introduced as steam, and the water produced in the wells of the oil fields, in order to determine the contributions of the various intervals to well production, as well as the influence of injected steam as a recuperation method. The isotopic compositions were characterized, including the water introduced as steam $\left(\delta^{2} \mathrm{H}=3 \%_{0}\right.$ and $\delta^{18} 0=0.5 \%$ ), the formation water in the reservoir $\left(-25 \% 0<\delta^{2} \mathrm{H}<\right.$ $-18 \%$ and $-4.1 \% 0<\delta^{18} 0<-2.6 \%$ ), and the water produced from wells with specific or combined production intervals in the Açu reservoir. The results help to determine the differential participation of the various production intervals in wells with combined production, as well as the isotopic and energetic influence of the injected steam in wells adjacent to the injection wells. Finally, it was possible to identify the effects of oil biodegradation, as evidenced by high concentrations of dissolved inorganic carbon (DIC) enriched with ${ }^{13} \mathrm{C}$.
\end{abstract}

Keywords: formation water, environmental isotopes, biodegradation, secondary recovery.

RESUMO. Os campos Alto do Rodrigues, Estreito e Salina Cristal, da Bacia Potiguar, produzem óleo pesado proveniente de diferentes intervalos de produção, na Formação Açu. Para estimular a produção, vem sendo utilizada a injeção de vapor, gerado a partir de água do rio Açu. Este trabalho apresenta um estudo das características físico-químicas e isotópicas de águas superficiais da região, da água introduzida como vapor, e da água produzida em poços daqueles campos, tendo como objetivo identificar a contribuição de diferentes intervalos na produção dos poços, e a influência do vapor injetado como método de recuperação. Foi caracterizada a composição isotópica da água introduzida como vapor $\left(\delta^{2} \mathrm{H}=3 \%\right.$ e $\delta 180=0,5 \%$ ) , da água de formação do reservatório $\left(-25 \% 0<\delta^{2} \mathrm{H}<-18 \%\right.$ o e $-4,1 \% 0<\delta 180<-2,6 \%$ o $)$ e da água produzida em poços com produção em intervalos específicos ou combinados do reservatório Açu. A partir dos resultados obtidos, foi possível determinar a participação diferenciada nos poços com produção combinada dos diferentes intervalos produtores, e a influência isotópica e energética do vapor injetado nos poços vizinhos ao poço injetor. Também foi possível identificar o efeito da biodegradação nos óleos, evidenciados pela alta concentração do carbono inorgânico dissolvido (CID) enriquecido em $\mathrm{C}^{13}$.

Palavras-chave: água de formação, isótopos ambientais, biodegradação, recuperação secundária.

\footnotetext{
$1_{1}$ Instituto Federal do Mato Grosso do Sul, Campus Dourados, Dourados, MS, Brazil. Phone: +55(67) 3410-8500 - E-mail: danilo.teles@ifms.edu.br

${ }^{2}$ Universidade Federal da Bahia, Instituto de Física, Centro de Pesquisa em Geofísica e Geologia, Salvador, BA, Brazil. Phones: +55(71) 3283-6680/3283-6691

- E-mails: expedito@ufba.br; albarcos@gmail.com; mrzucchi@gmail.com; renatxai@yahoo.com.br

3 Petrobras, Research and Development Center (CENPES), Division of Geochemistry, Rua Horácio Macedo, 950, Ilha do Fundão, 21941-915 Rio de Janeiro, RJ, Brazil.

Phone: +55(21) 2162-7454 - E-mail: alexandreaf@petrobras.com.br

${ }^{4}$ Consultor independente - E-mail: santosnetoeugenio@gmail.com

${ }^{5}$ Instituto Federal da Bahia, Campus Valença, Valença, BA, Brazil. Phone: +55(75) 3641-3051 - E-mail: tarciohenrique@gmail.com
} 


\section{INTRODUCTION}

Isotopic analyzes of water in mature fields can be used as tracer in the secondary recovery of reservoirs, in order to evaluate their influence in different production intervals. Currently favored techniques, which are based on the analysis of hydrocarbons, cannot be applied to this analysis, due to the changes that occur as a result of biodegradation. Isotopic $\delta^{13} \mathrm{C}$ data also fail in providing an effective analysis, as the oils are derived from same source with similar thermal evolution levels, causing them to have the same isotopic identity. Alternative chemometric methods are also difficult to apply; this is due to the oils being from the same source and presenting similar thermal evolution levels, causing them to have the same isotopic identity. Thus, analysis of the isotopic compositions of formation waters is a viable option for this study, as it is able to distinguish waters from different sources.

Steam injection raises the temperature of the treated reservoirs, and the resulting decrease in viscosity and increased flow is the source of this technique's utility. Vaporized water is used for this process, given its high latent heat of vaporization, and the heat required for this approach is generated on the surface and transported to the interior of the formation, where, using selective completion, the gaseous fluid is injected only into the reservoirs that contain oil. This fluid, once injected into the subsurface, condenses, transferring heat to the oil and surrounding rock, and finally mixes with the formation water, altering its isotopic composition (Alvarez \& Han, 2013; Gu et al., 2015).

Beneath the surface, the injected steam moves in multiple directions, flowing through fractures and pores, and following more favorable routes, it may mix with the formation water in the wells. The introduced fluid is hotter than the formation water and has distinct isotopic characteristics, meaning that it can influence it both energetically, through heat exchange, and isotopically, by modifying its isotopic signature (Nian et al., 2014).

In the Aguilhada and Castanhal fields of the Sergipe Basin, Brazil, the connectionsbetween aquifers have been studied by Teles et al. (2010), alongside the effects ofbiodegradation, revealing evidence of interactions between local aquifers. The samples showed much smaller variation for $\delta^{18} 0$ than for $\delta^{2} \mathrm{H}$, which has been interpreted as evidence of a possible exchange with $\mathrm{H}^{2} \mathrm{~S}$. Alternatively, the high concentrations of dissolved inorganic carbon (DIC) enriched with ${ }^{13} \mathrm{C}$ suggest that this difference in isotopic variation is the result of oil biodegradation and methanogenesis.

The large quantity of heavy oils and the exhaustion of sources that are accessible through primary recovery in the fields of the Potiguar Basin require recovery methods that can maximize hydrocarbon retrieval. Thermal methods, especially steam injection, are the most notable of these techniques, due to the advanced development of the technology, the rapid increase in production it affords, as well as other factors (Queiroz, 2005).

This study presents isotopic analyses of produced water from onshore fields of the Potiguar Basin in Brazil, where steam is injected for the secondary recovery of heavy oils, with the aim of assessing the percentage of oil derived from different production intervals, using the isotopic composition of produced water as a tracer.

\section{STUDY AREA}

Located in the easternmost portion of northeastern Brazil, the Potiguar Basin covers parts of the states of Rio Grande do Norte and Ceará, as well as their respective continental shelves. It was first explored in 1951, and covers a total area of 119,300 km². Its southern, eastern, and western limits are bounded by crystalline basement rocks, while its northern limit is bounded by the Atlantic Ocean, and its northeastern limit is bounded by the Alto de Fortaleza, which separates it from the Ceará Basin (Fig. 1) (Araripe \& Feijó, 1994).

The lithotypes in the basin belong to three groups: the Areia Branca, Apodi, and Agulha groups (Pessoa Neto et al., 2007). The Açu Formation, in which the studied fields are located, belongs to the Apodi Group, which comprises mainly siliciclastic and carbonate rocks. This group also contains the Ponta do Mel, Quebradas, and Jandaíra formations, with a discordant stratigraphic boundary between the Açu and Alagamar formations. The Açu and Ponta do Mel formations together form a transgressive marine system. The rock types of the former range from conglomerates to mudstones and belongs to a continental transgressive sequence of Albo-Cenomanian age (Bertani et al., 1990), while the latter formation consists of carbonate rocks, believed to be of shallow marine origin (Araripe \& Feijó, 1994).

Large portion of the oil produced in the Potiguar Basin is heavy and viscous, while a small fraction is biodegraded (Parente, 2006). Commercial heavy oil production began in this region in 1981, and today depends on the application of thermal methods to maintain high pressure in the reservoirs. Currently, the Potiguar Basin produces an average of $3,402,000 \mathrm{~m}^{3}$ of oil per year, having increased significantly between 2008 and 2010 (ANP, 2013).

Overall, the occurrence of oil in the Potiguar Basin is principally due to the presence of mature source rocks, along with strong structural and stratigraphic controls. There are three main heavy oil fields in this basin: Estreito, Alto do Rodrigues, and Fazenda Belém. The first two, located in the Carnaubais trend, 


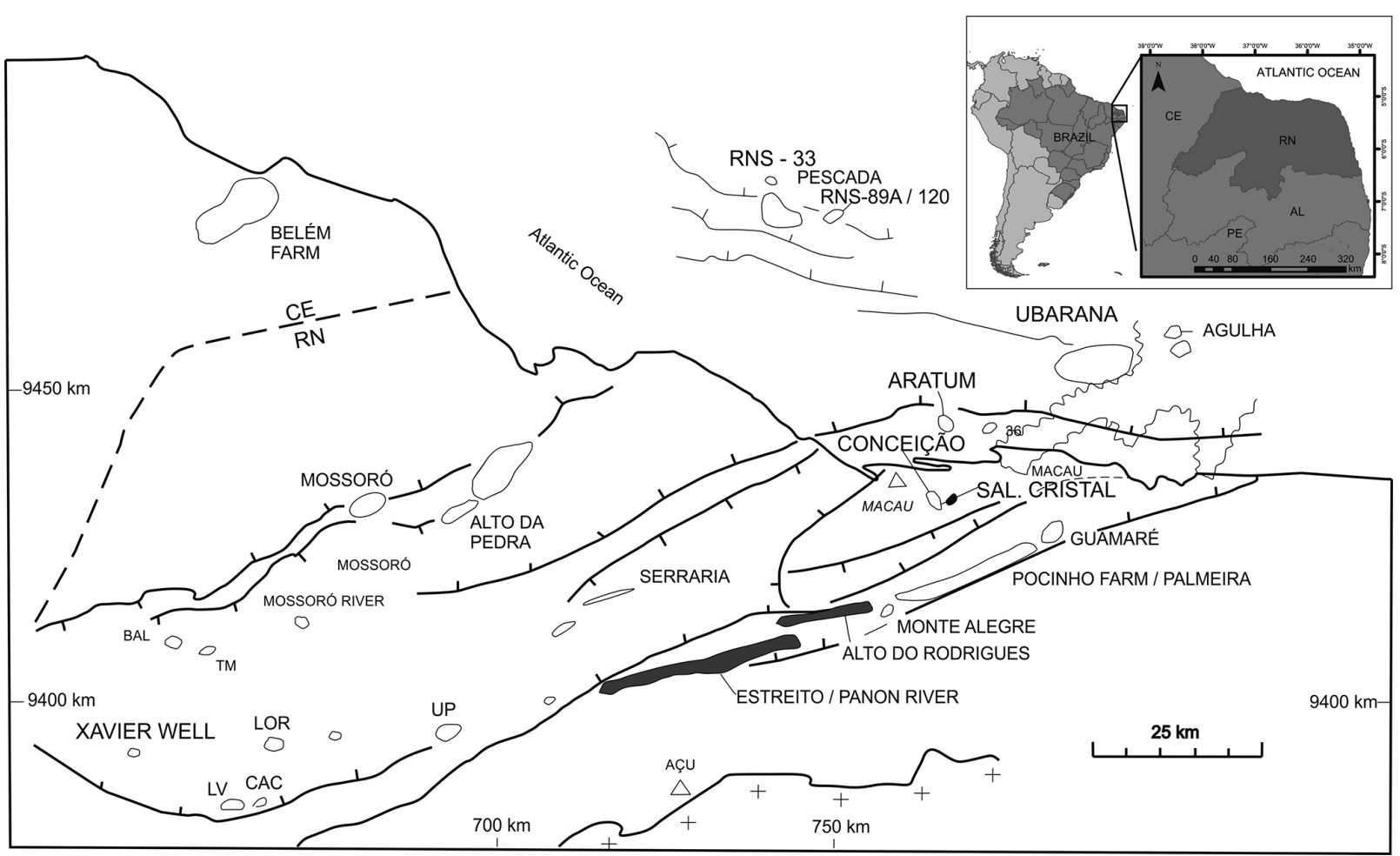

Figure 1 - Location of the principal oil fields in the Potiguar Basin. The Salina Cristal, Alto do Rodrigues, and Estreito fields have oil with high levels of $\mathrm{H}^{2} \mathrm{~S}$, and are located in the state of Rio Grande do Norte (Adapted from Castro \& Barrocas, 1981).

have reservoirs located at the top of the Açu-3 unit, which is the same location as the Salina Cristal field (Fig. 1).

In the Estreito and Alto do Rodrigues fields, there are specific areas for oil production through secondary recovery, in which thermal fluids are used separately or concurrently in two or more zones. In these cases, the proportion of oil produced from each area is unknown, since the available techniques that could be used to distinguish oil sources are typically based on $\delta^{13} \mathrm{C}$ analysis of the lighter hydrocarbons, and such techniques are ineffective due to both the consistency of isotopic values, and the fact that isotopic data for heavier oils are not comparable. Other chemometric methods are difficult to employ, given that the oils are from the same source with similar thermal evolution levels (Santos Neto \& Hayes, 1999). Therefore, the variation in the hydrogen $\left(\delta^{2} \mathrm{H}\right)$ and oxygen $\left(\delta^{18} 0\right)$ isotopes of formation water suggesting that they can be used as a robust and an efficient method for estimating the proportional volume of oil produced in each zone.

From the perspective of reservoir engineering, aquifers can be classified as either deep aquifers, comprising underlying reservoirs, or lateral aquifers. Both occur in the Açu Formation, as illustrated in Figure 2. In this formation, the aquifers related to the hydrocarbon reservoirs, are, for the most part, small and mini- mally active, and thus the implementation of water injection and reinjection projects is fundamental to the exploitation of oil deposits in this unit.

\section{MATERIAL AND METHODS}

In total, 42 formation water samples were collected and analyzed: 09 from the Salina Cristal field, 12 from the Estreito field, and 21 from the Alto do Rodrigues field. The sampled wells were selected in consideration of the different levels of extraction in the Açu reservoir: 24 wells access specific levels for production, while 18 combine different production intervals.

In order to control the isotopic characterization of the water utilized in the thermal recovery process, seven additional water samples were analyzed. These were taken from the Açu River, the water used for steam production, the water leaving the steam generator, and the condensed steam.

Following the protocol established by Lemay (2002), the samples were collected at the wellhead in $5 \mathrm{~L}$ polyethylene flasks, and, after oil separation, were filtered through a $0.45 \mu \mathrm{m}$ filter. The $\mathrm{pH}$, electrical conductivity, and titration of the filtered samples were measured, after which they were placed in glass flasks for subsequent treatment and isotopic measurements. 

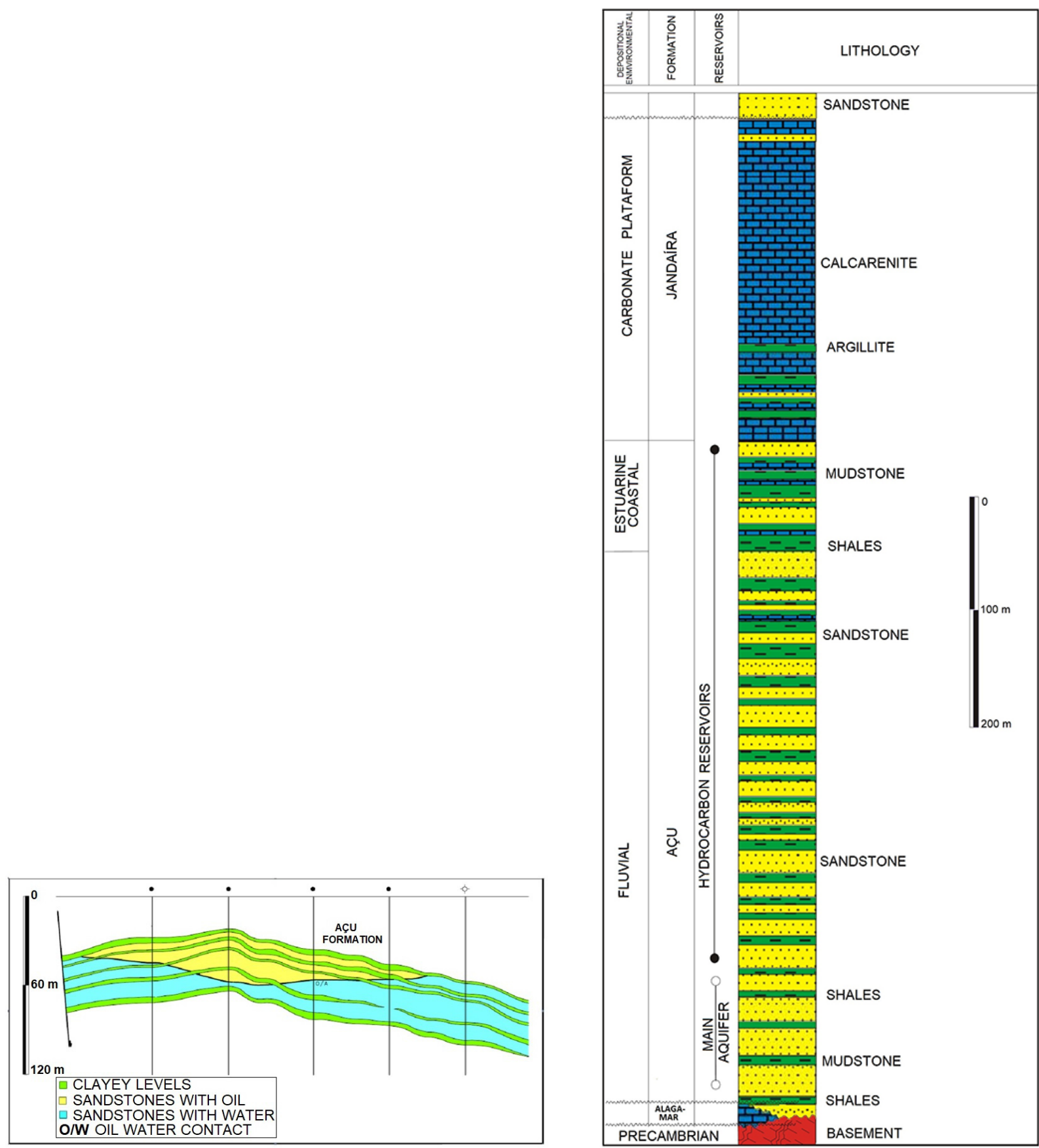

Figure 2 - Illustative geological schematic section of the aquifer at the bottom of the Açu Formation and typical stratigraphic profile of the Açu Formation. Highlighting the lithostratigraphic column of the oil reservoirs and the principal aquifer of the unit, focused at its base. (Preda et al., 2008).

The oxygen and deuterium isotopic measurements were acquired from Cavity Ring-Down Spectroscopy (CRDS) of the samples. This technique determines the isotopic ratios of hydrogen and oxygen in water, using the absorption spectra of $\mathrm{H}^{2} \mathrm{O}$ molecules (Berden \& Engeln, 2009).
Measurements of the dissolved inorganic carbon (DIC) isotopic ratio were accomplished using a gas-bench system coupled to a Delta Plus Thermo-Finnigan spectrometer (Teles et al., 2014). The isotopic values are expressed in the conventional delta notation, with the results represented in parts per thousand, as per the 
Vienna SMOW standard for hydrogen and oxygen and the Vienna PDB standard for carbon. All isotopic measurements were made at the Applied Nuclear Physics Laboratory of the Universidade Federal da Bahia.

\section{RESULTS AND DISCUSSION}

The measured values are presented in Tables 1 and 2. In the studied wells, oil extraction is performed from specific or combined intervals (Fig. 2). The fields are mature, and therefore require specialized recovery methods. The results presented in Table 1 indicate that the change in the physical state of the water used for such methods did not significantly alter its isotopic concentration.

Table 1 - Results from isotopic and physicochemical analyses of the samples taken from the surface and subterranean waters used in secondary recovery.

\begin{tabular}{|l|c|c|c|c|}
\hline \multicolumn{1}{|c|}{ Sample } & $\begin{array}{c}\delta^{18} 0 \\
(\%)\end{array}$ & $\begin{array}{c}\delta^{2} \mathrm{H} \\
(\% 0\end{array}$ & $\begin{array}{c}\delta^{13} \mathrm{C} \\
(\%)\end{array}$ & $\begin{array}{c}\mathrm{DIC} \\
(\mathrm{mmol} / \mathrm{l})\end{array}$ \\
\hline Water from the Açu River & 0.3 & 3 & -10.1 & 2 \\
\hline Water used to generate steam & 0.5 & 3 & -10.0 & 2 \\
\hline Water leaving the steam generator & 0.1 & 3 & 9.3 & 1 \\
\hline
\end{tabular}

The water leaving the steam generator, obtained after it had completely condensed, exhibited an isotopic composition similar to the water used to generate the steam, specifically, $\delta^{2} \mathrm{H}=3 \%$ and $\delta^{18} 0=0.5 \%$. Considering that all of the fluid was vaporized and injected into the reservoirs, the condensed vapor in the subsurface should have an isotopic composition similar to the water used for steam generation, and that these values characterize the isotopic features of the injected water.

The isotopic identity of the formation water in the Açu reservoir seems to be represented by the values of the samples from the Salina Cristal field, whose intervals are deeper than those for the Alto do Rodrigues and Estreito fields. In contrast to the latter two, the Salina Cristal field was not subjected to fluid injection recovery processes. Its isotopic composition is fairly homogenous, with $\delta^{2} \mathrm{H}$ values between $-26 \%$ and $-23 \%$ and $\delta^{18} 0$ values between $-4.7 \%$ and $-4.2 \%$, as illustrated in Figure 3 . The similarities in the isotopic composition, with more negative values for the subterranean water in the Açu aquifer, indicate a possible connection with the formation water in the Açu reservoir.

In the Estreito field samples, it was observed that the water derived exclusively from the 50/60 interval, ET 01, ET 02, and ET $03\left(\delta^{2} \mathrm{H} \approx-21 \%\right.$; $\left.\delta^{18} 0 \approx-4 \%\right)$, showed isotopic compositions close to the values found in the Salina Cristal field, and are therefore assumed to not be influenced by the injected water with $\delta^{2} \mathrm{H} \approx 1 \%$ and $\delta^{18} 0 \approx-0.2 \%$ (Fig. 4). The samples for the 100 interval of this field $\left(\delta^{2} \mathrm{H} \approx 1 \% ; \delta^{18} \mathrm{O} \approx-0.2 \%\right.$ ) have a similar isotopic composition to the injected water. Among the samples obtained from a combination of the 50/60 and 100 intervals, isotopic compositions in wells ET 08, ET 10, and ET 11 are dominated by the values of the 50/60 interval, while wells ET 09 and ET 12 are dominated by the 100 interval. The participation of individual levels in samples derived from combined intervals differed in the isotopic results compared to the results of collecting temperature.

Among the Alto do Rodrigues field samples (Fig. 5), the 300 interval was homogeneous, with $\delta^{2} \mathrm{H}$ values between $-16 \%$ and $-14 \%$ and $\delta^{18} 0$ values between $-3.6 \%$ and $-3,1 \%$. The samples taken from the 100 and 140 intervals were more heterogeneous, with $\delta^{2} \mathrm{H}$ values ranging between $-15 \%$ and $0 \%$ and $\delta^{18} 0$ values between $-3.3 \%$ and $0.0 \%$. These values are consistent with a combination of isotopic characteristics of water from the 300 interval, and water that was injected $\left(\delta^{2} \mathrm{H} \approx 1 \% ; \delta^{18} 0\right.$ $\approx-0.2 \%$ ). The samples taken from the combined $100 / 140$ intervals have a homogeneous isotopic composition, similar to the 300 interval samples and the more negative samples from the 100 and 140 intervals. The samples taken from the combined 100/300 intervals are dominated by the isotopic characteristics of the 300 interval, while samples ARG 16 and ARG 17 are largely isotopically consistent with the injection water. The samples from the combined 100/140/300 level demonstrate, for wells ARG 18, ARG 19, and ARG 20, major influences from the 300 or 140 levels, while well ARG 21 shows more significant participation from the injection waters.

An analysis of Figure 6 reveals, with some certainty, significant differences in the participation of the different levels in wells drawing from combined intervals, suggesting that the isotopic analysis of associated waters can be used to identify the influence of vapor injection recovery on the production wells. It may be noted that wells with isotopic values close to those of the vapors are likely to suffer more from their influence.

\section{Temperature of the Collected Samples}

Figure 7 shows that although some samples (ARG 01, ARG 11, and ET 11) exhibited temperatures on the order of $100^{\circ} \mathrm{C}$, they had isotopic compositions depleted in deuterium $\left(\delta^{2} \mathrm{H} \approx-15 \%\right)$. This suggests that there is no mixing between the condensed steam that was injected and the formation water of the reservoir, despite a notable heat flow in the direction of these wells to cause the increase in fluid temperature. This may have occurred, probably, as a result of the absence of faults and fractures in the rocks, which may have prevented the passage of fluid, but not heat, between the wells. 
Table $2-\delta^{18} 0$ and $\delta^{2} \mathrm{H}$ isotopic compositions of formation water samples collected from Estreito (ET sample codes), Salina Cristal (SCR sample codes), and Alto do Rodrigues (ARG sample codes) fields. Temp. is the temperature of water at the well head.

\begin{tabular}{|c|c|c|c|c|c|c|}
\hline Sample & Zone & $\begin{array}{c}\text { Temp. } \\
\left({ }^{\circ}\right)\end{array}$ & $\begin{array}{l}\delta^{18} 0 \\
(\% 0)\end{array}$ & $\begin{array}{l}\delta^{2} \mathrm{H} \\
(\% 0)\end{array}$ & $\begin{array}{l}\delta^{13} \mathrm{C} \\
(\% 0)\end{array}$ & $\begin{array}{c}\text { DIC } \\
(\mathrm{mmol} / \mathrm{l})\end{array}$ \\
\hline ET 01 & $50 / 60$ & 44 & -3.9 & -20 & 16.5 & 13 \\
\hline ET 02 & $50 / 60$ & 52 & -4.5 & -24 & -2.8 & 12 \\
\hline ET 03 & $50 / 60$ & 39 & -3.5 & -19 & 9.7 & 12 \\
\hline ET 04 & 100 & 100 & -0.4 & 0 & -3.7 & 5 \\
\hline ET 05 & 100 & 36 & -0.2 & 1 & -6.3 & 12 \\
\hline ET 06 & 100 & 99 & 0.2 & 1 & -2.0 & 3 \\
\hline ET 07 & 100 & 96 & -0.2 & 0 & 10.9 & 4 \\
\hline ET 08 & $50 / 60+100$ & 41 & -4.6 & -23 & -12.7 & 10 \\
\hline ET 09 & $50 / 60+100$ & 81 & 0.1 & -2 & 16.2 & 5 \\
\hline ET 10 & $50 / 60+100$ & 58 & -3.9 & -20 & 14.1 & 13 \\
\hline ET 11 & $50 / 60+100$ & 95 & -4.1 & -22 & 13.2 & 4 \\
\hline ET 12 & $50 / 60+100$ & 99 & -0.5 & -2 & 9.3 & 5 \\
\hline SCR 01 & 350 & 45 & -4.3 & -23 & 13.0 & 31 \\
\hline SCR 02 & 350 & 44 & -4.3 & -24 & 13.8 & 30 \\
\hline SCR 03 & 350 & 49 & -4.4 & -24 & 18.0 & 26 \\
\hline SCR 04 & 400 & - & -4.5 & -26 & 21.0 & 24 \\
\hline SCR 05 & 400 & 41 & -4.3 & -24 & 18.3 & 28 \\
\hline SCR 06 & 400 & 49 & -4.2 & -23 & 12.8 & 33 \\
\hline SCR 07 & 400 & 47 & -4.7 & -25 & 14.9 & 20 \\
\hline SCR 08 & $350+400$ & 46 & -4.3 & -24 & 11.3 & 28 \\
\hline SCR 09 & $350+400$ & 49 & -4.4 & -24 & 5.3 & 28 \\
\hline ARG 01 & 100 & 100 & -3.3 & -15 & 4.8 & 2.6 \\
\hline ARG 02 & 100 & 93 & 0 & 0 & 2.2 & 4.3 \\
\hline ARG 03 & 100 & 53 & -2.5 & -11 & 8.1 & 9.3 \\
\hline ARG 04 & 100 & 37 & -0.8 & -4 & 11.4 & 11.1 \\
\hline ARG 05 & 140 & 37 & -3.1 & -14 & -11.3 & 5.5 \\
\hline ARG 06 & 140 & 97 & -0.6 & -3 & 1.5 & 2.3 \\
\hline ARG 07 & $100 / 140$ & 60 & $-3,4$ & -16 & -4.1 & 9.1 \\
\hline ARG 08 & $100 / 140$ & 43 & -3.4 & -14 & -4.5 & 5.2 \\
\hline ARG 09 & $100 / 140$ & 60 & -3.1 & -13 & 9.5 & 8.4 \\
\hline ARG 10 & $100 / 140$ & 39 & -2.9 & -13 & 6.7 & 8.6 \\
\hline ARG 11 & 300 & 94 & -3.5 & -16 & 1.4 & 8.2 \\
\hline ARG 12 & 300 & 41 & -3.6 & -16 & 0.3 & 7.6 \\
\hline ARG 13 & 300 & 64 & -3.1 & -14 & -0.8 & 6.3 \\
\hline ARG 14 & 300 & 42 & -3.1 & -14 & 16.3 & 9.1 \\
\hline ARG 15 & $100 / 300$ & 38 & -3.3 & -16 & 5.4 & 8.0 \\
\hline ARG 16 & $100 / 300$ & 100 & -0.6 & -5 & -1.2 & 2.3 \\
\hline ARG 17 & $100 / 300$ & 65 & 0.2 & 1 & 6.7 & 4.2 \\
\hline ARG 18 & $100 / 140 / 300$ & 43 & -2.9 & -14 & 4.5 & 7.7 \\
\hline ARG 19 & $100 / 140 / 300$ & 47 & -3.4 & -17 & -2.5 & 7.2 \\
\hline ARG 20 & $100 / 140 / 300$ & 77 & -3.3 & -15 & 15.8 & 6.6 \\
\hline ARG 21 & $100 / 140 / 300$ & 100 & -1 & -4 & 3.6 & 3.3 \\
\hline
\end{tabular}




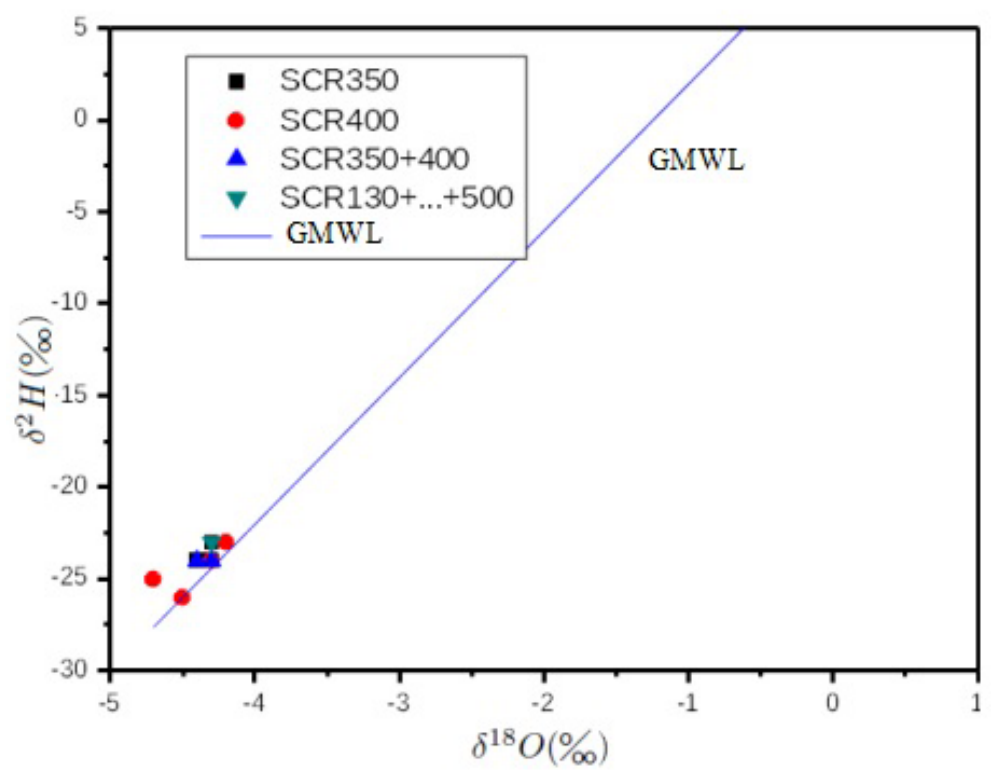

Figure 3 - Graph of $\delta^{2} H$ vs. $\delta^{18} 0$ for the Salina Cristal field, with an average isotopic composition of $\delta^{2} \mathrm{H}=-24 \%$ and $\delta^{18} 0=-4.4 \%$. The samples were consistent with the Global Meteoric Water Line (GMWL: $\delta^{2} H=8^{\star} \delta^{18} 0+10 \%$. Craig, 1961).

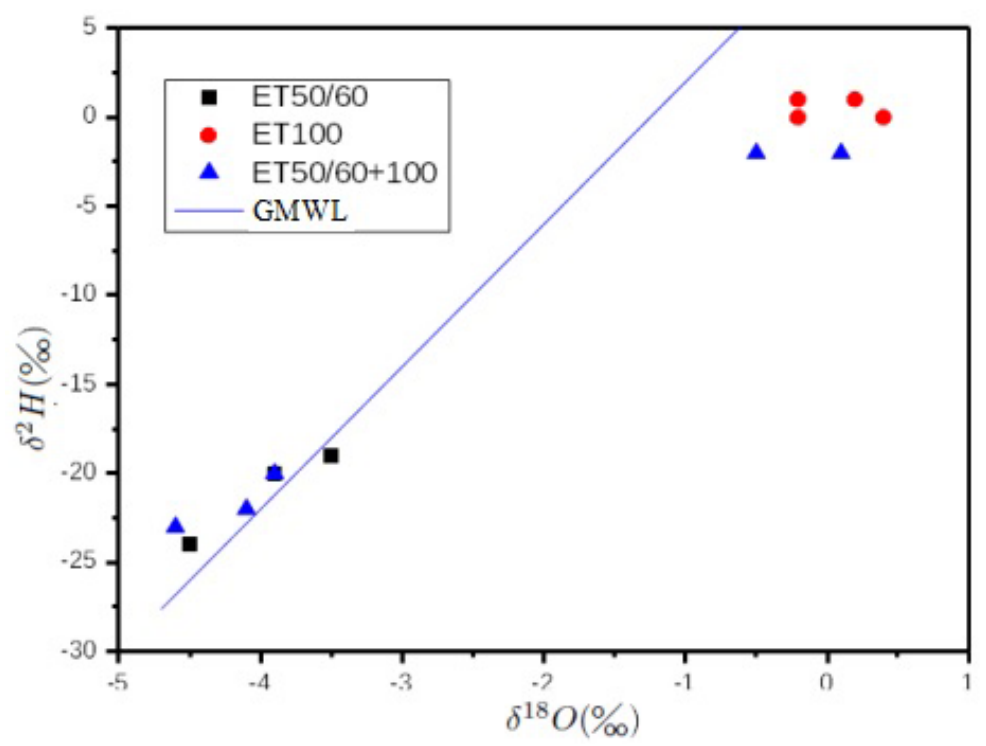

Figure 4 - Graph of $\delta^{2} \mathrm{H}$ vs. $\delta^{18} 0$ for the Estreito field. The samples are divided into two distinct groups: one that is closer to the GMWL and that has an isotopic composition similar to the SCR field; and another, restricted to the upper right portion of the GMWL: $\delta^{2} H=8^{*} \delta^{18} 0+10$ (Craig, 1961), with an isotopic composition that is heavier in both hydrogen and oxygen than the other samples.

Figure 7 also shows that one sample with a temperature of less than $50^{\circ} \mathrm{C}$ still had a similar isotopic composition to that of the injected water. In this case, it seems that this well, despite being located far from the injection points, is still connected to them via fractures that create a path for the injected fluid. In such a situation, the fluid would continuously lose heat to the surroundings while travelling, but the deuterium and oxygen isotopic concentrations would remain constant. 


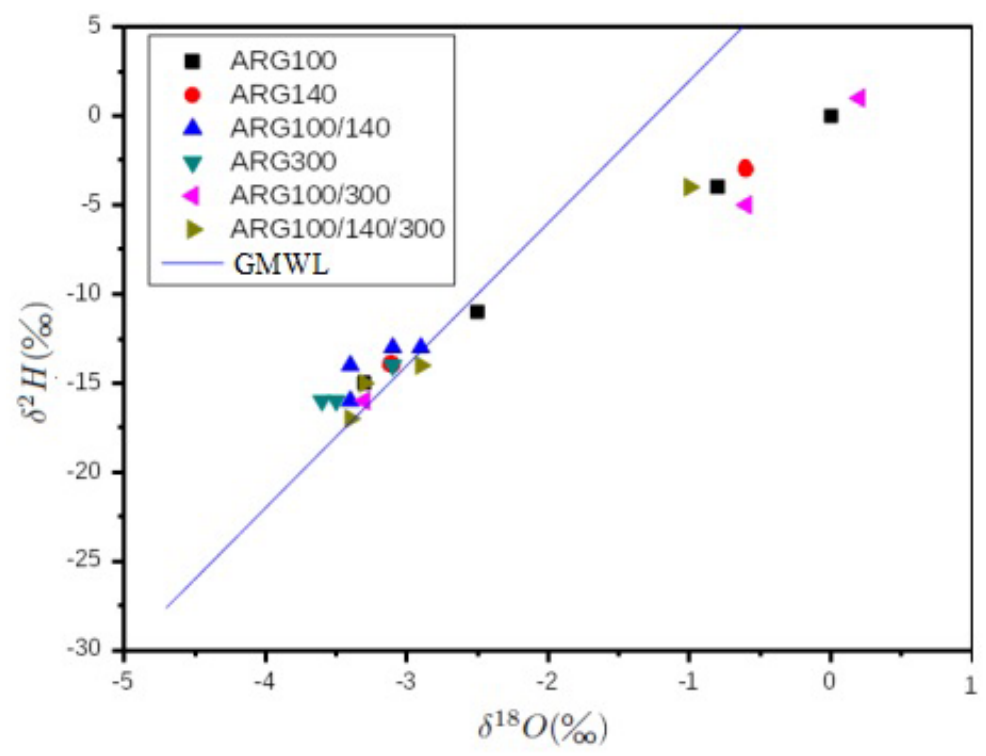

Figure $\mathbf{5}$ - Graph of $\delta^{2} \mathrm{H} v$ s. $\delta^{18} \mathrm{O}$ for the Alto do Rodrigues field. Similar to the samples from the Estreito field, two isotopically distinct groups appear. The majority of the samples occupy the group of more depleted isotopic values, while the other, less depleted group is composed of samples from different levels of this field.

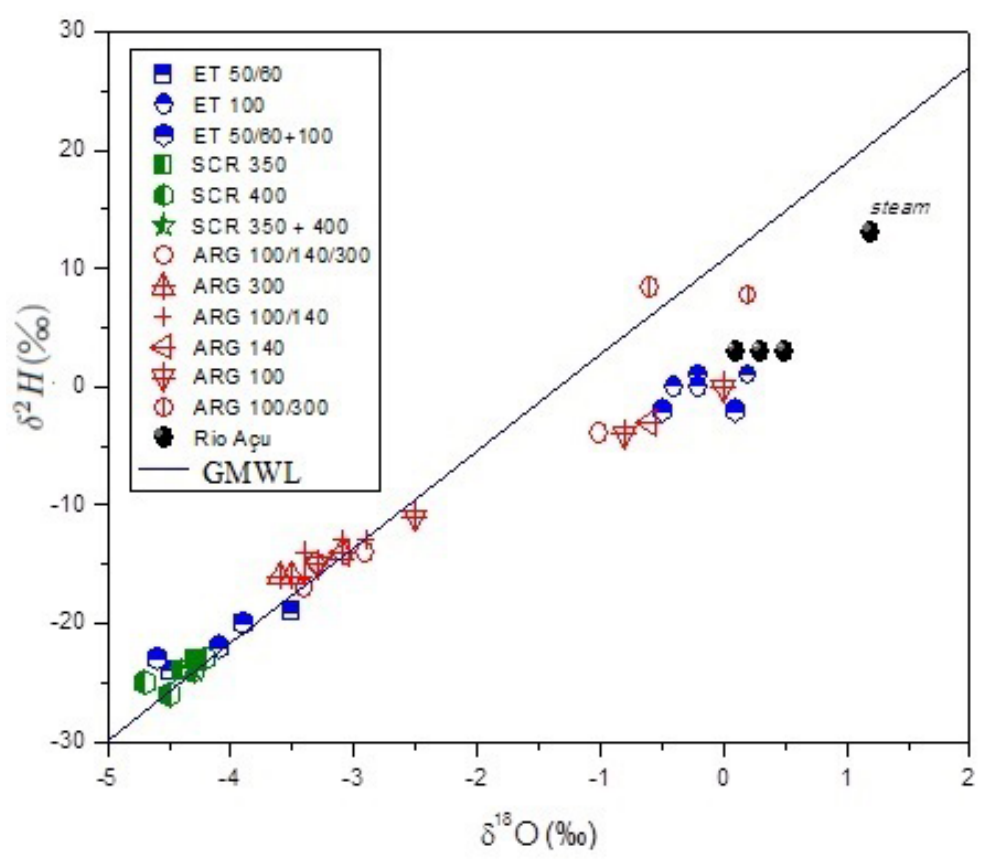

Figure 6 - Graph of $\delta^{2} \mathrm{H}$ vs. $\delta^{18} 0$ for the fields analyzed in the Potiguar Basin and for the water used in steam production.

\section{Concentration and Isotopic Composition of DIC}

An analysis of the data in Tables 1 and 2, reveals that some of the samples exhibit elevated $\delta^{13} \mathrm{C}$ values and higher levels of DIC. These can be accounted for by biodegradation processes, such as microorganism-mediated methanogenesis, which generates methane strongly depleted in ${ }^{13} \mathrm{C}$, as well as $\mathrm{CO}^{2}$ strongly enriched in this isotope.

The biodegradation of oils is commonly attributed to the activity of microorganisms that proliferate in reservoirs in different 


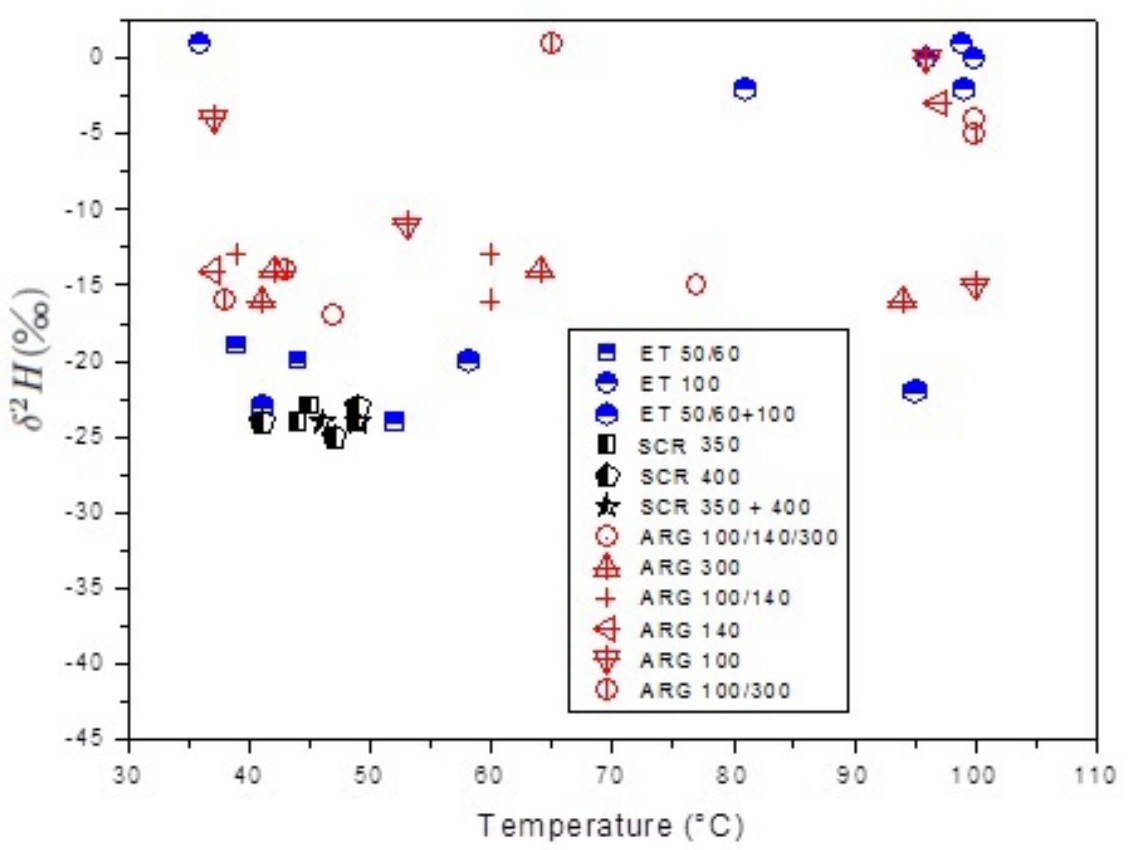

Figure 7 - A graph of $\delta^{2} \mathrm{H} v$ s. temperature for samples in the Estreito, Salina Cristal, and Alto do Rodrigues fields. The majority of the "cold" samples have an isotopic composition that is relatively depleted in deuterium when compared to the majority of the "hot" samples, which presented an isotopic composition similar to the injected fluid.

areas. Da Cruz et al. (2011) studied petroleum biodegradation in deep sea reservoirs, and suggested that both aerobic and anaerobic bacteria usually act as a consortium. Their evidence suggests that aerobic biodegradation is mainly responsible for the depletion of linear hydrocarbons, with an even-to-odd carbon preference, while anaerobic biodegradation was observed to have an odd-toeven carbon preference. Their observation that mixed aerobic and anaerobic consortia displayed periods of $\mathrm{C}$-even preference and periods of C-odd preference implies the existence of alternating aerobic and anaerobic lifecycles.

Head et al. (2003) and Jones et al. (2007) have discussed the roles of anaerobic processes during degradation, including both methanogenesis and a variety of other processes involved in the reduction of sulfates, nitrates, and iron. They also assess aerobic methanogenesis, which, along with the other processes, can affect the isotopic distributions of carbon and hydrogen in the fluids present in reservoirs. While analyzing the sources and destinations of DIC in interstitial water, Hellings et al. (2000) confirmed that the $\delta^{13} \mathrm{C}$ concentration of DIC in reducing environments is strongly enriched as a result of methanogenesis.

Figure 8 shows that the data from the Salina Cristal samples, whose formation water underwent no dilution from the introduced steam, show generally high DIC concentrations, between 20 and $32 \mathrm{mmol} / \mathrm{L}$, and very positive $\delta^{13} \mathrm{C}$ values, ranging from $5.3 \%$ to
21.0\% . In the samples from the Alto do Rodrigues and Estreito fields, both the DIC concentration and $\delta^{13} \mathrm{C}$ values vary significantly, from 2 to $32 \mathrm{mmol} / \mathrm{L}$, and from $-12.7 \%$ to $16.5 \%$, respectively. This demonstrates the effects of variable mixing between the introduced steam with the original formation water.

\section{CONCLUSIONS}

The water vapor injected into the Estreito and Alto do Rodrigues fields has isotopic values very different from the Açu aquifer and from the formation water of the reservoirs in the Açu Formation. The difference between the isotopic compositions of the water used for secondary recovery and those of the water originally in the reservoir permits these variables to be used as tracers in determining the influence of injected water on the water extracted from production wells in the terrestrial Potiguar Basin. It was possible to identify the wells in the Estreito and Alto do Rodrigues fields in which the steam injection fully replaced the original formation water, in which the produced water showed no isotopic changes, and in which the injection water mixed with the original formation water.

The concentrations and isotopic compositions of DIC from the fields are distributed over a large range of values, indicating the great potential of this parameter to aid in better understand- 


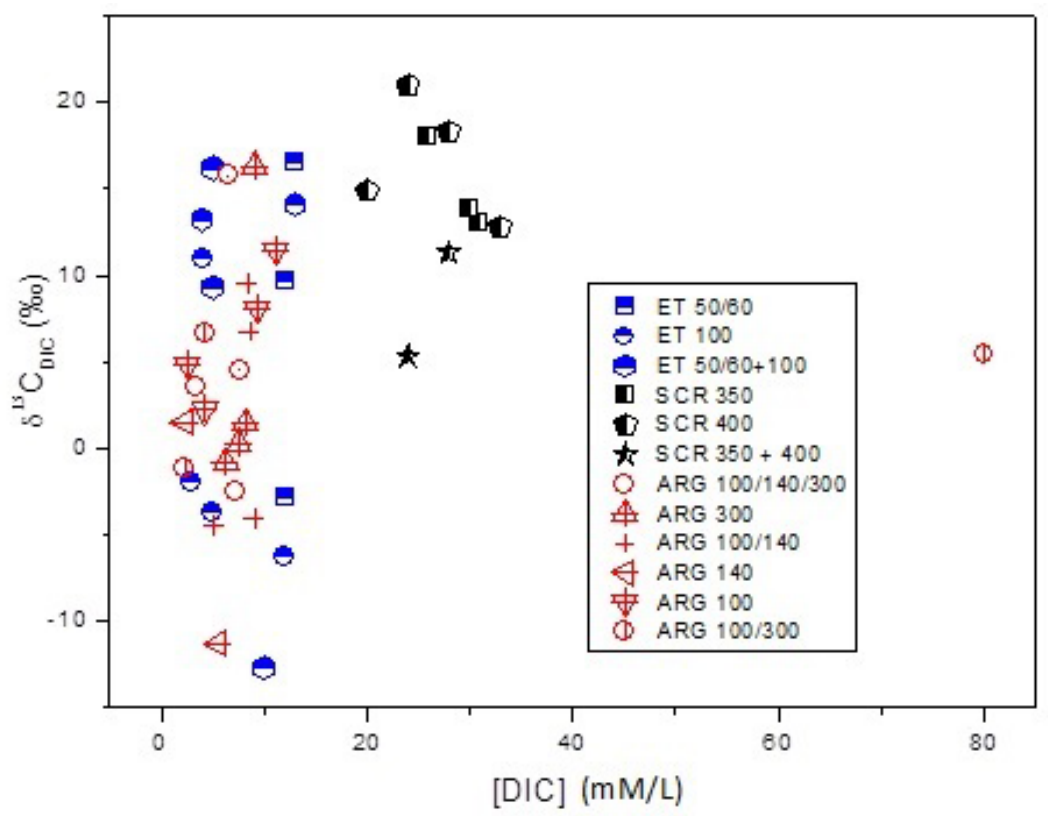

Figure 8 - Graph of $\delta^{13} \mathrm{C} v$ S. DIC concentration in the sampled fields of the Potiguar Basin.

ing the major processes that occur in reservoirs affected by both the interactions between water and rocks, and biodegradation. In order to more fully understand these data and utilize them effectively, it will be necessary to compare and integrate them with the isotopic values of the gases, oils, and carbonate minerals present in the studied reservoirs.

\section{ACKNOWLEDGEMENTS}

The first author is thankful for the scholarship granted by Capes that was used to complete the doctoral work that contributed to this paper. The authors are equally grateful to Petrobras of Rio Grande do Norte, especially to Abel Gomes, who was fundamental to the conclusion of this research. The authors thank the Petrobras Research and Development Center (CENPES), Division of Geochemistry, who made this research possible, and Applied Nuclear Physics Laboratory for the equipment and human resources funding.

\section{REFERENCES}

ALVAREZ J \& HAN S. 2013. Current Overview of Cyclic Steam Injection Process. Journal of Petroleum Science Research, 2: 116-127.

ANP. 2013. Anuário estatístico brasileiro do petróleo e do gás natural. Rio de Janeiro: Agência Nacional do Petróleo, Gás Natural e Biocombustíveis. 236 pp. Available on: <http://www.anp.gov.br/?pg=58351m= $\mathrm{t} 1=\mathrm{t} 2=\mathrm{t} 3=\mathrm{t} 4=\mathrm{ar}=\mathrm{ps}=\mathrm{cachebust}=1331486357832>$. Access on: May 08, 2014.
ARARIPE PDT \& FEIJÓ FJ. 1994. Bacia Potiguar. Boletim de Geociências da Petrobras, 8(1): 127-141.

BERDEN G \& ENGELN R. 2009. Cavity Ring-Down Spectroscopy Techniques and Applications. United Kingdom: John Wiley Sons Ltd., 344 pp.

BERTANI RT, COSTA IG \& MATOS RMD. 1990. Evolução tectonosedimentar, estilo estrutural e habitat do petróleo na Bacia Potiguar. In: RAJA GABAGLIA GP \& MILANI EJ. Origem e Evolução de Bacias Sedimentares. Rio de Janeiro: Petrobras, 2: 291-310.

CASTRO JC \& BARROCAS SL. 1981. Roteiro de Campo, Fácies da Formação Açu, Bacia Potiguar. Petrobras/Cenpes, Rio de Janeiro, Brazil. Relatório Interno, $32 \mathrm{pp}$.

CRAIG H. 1961. Isotopic variations in meteoric waters. Science, 133: 1702-1703.

DA CRUZ GF, DE VASCONCELLOS SP, ANGOLINI CFF, DELLAGNEZZE BM, GARCIA INS, OLIVEIRA VM, SANTOS NETO EV \& MARSAIOL AJ. 2011. Could petroleum biodegradation be a joint achievement of aerobic and anaerobic microorganisms in deep sea reservoirs? AMB Express 1 : $10 \mathrm{pp}$.

GU H, CHENG L, HUANG S, LI B, SHEN F, FANG W \& HU C. 2015. Steam injection for heavy oil recovery: modeling of wellbore heat efficiency and analysis of steam injection performance. Energy Conversion and Management, 97: 166-177.

HEAD IM, JONES DM \& LARTER SR. 2003. Biological activity in the deep subsurface and the origin of heavy oil. Nature, 426: 344-352.

HELLINGS L, VAN DEN DRIESSCHE K, BAEYENS W, KEPPENSE \& DEHAIRS F. 2000. Origin and fate of dissolved inorganic carbon in intersti- 
tial waters of two freshwater intertidal areas: A case study of the Scheldt Estuary, Belgium. Biogeochemistry, 51(2): 141-160.

JONES DM, HEAD IM, GRAY ND \& LARTER SR. 2007. Crude-oil biodegradation via methanogenesis in subsurface petroleum reservoirs. Nature, 451(7175): 176-180.

LEMAY TG. 2002. Sampling of formation water from wells in the Athabasca oil sands (in Situ) Area, Alberta, 1999-2001. A Compilation of Protocols and Methods. Alberta Energy and Utilities Board, EUB/AGS Geo-Note 11. 40 pp.

NIAN YL, CHENG WL, LI TT \& WANG CL. 2014. Study on the effect of wellbore heat capacity on steam injection well heat loss. Applied Thermal Engineering, 70(1): 763-769.

PARENTE PF. 2006. Avaliação das condições de biodegradação do petróleo a partir da caracterização de parâmetros físico-químicos das águas e óleos da Formação Açu na Bacia Potiguar, RN-Brasil. Master Dissertation on Engineering - Coordenação dos Programas de PósGraduação de Engenharia (COPPE), Universidade Federal do Rio de Janeiro, Brazil, 2006. 120 pp.

PESSOA NETO OC, SOARES UM, SILVA JGF, ROESNER EH, FLORENCIO CP \& SOUZA CAV. 2007. Bacia Potiguar. Boletim de Geociências da Petrobras, 15(2): 357-369.
PREDA WN, ALENCAR FILHO MQ \& BORBA GL. 2008. Características gerais dos projetos de injeção de água nos reservatórios produtores de petróleo da Formação Açu na Bacia Potiguar. In: XV Congresso Brasileiro de Águas Subterrâneas, Natal, RN, Brazil, 2008. 16 pp.

QUEIROZ G0. 2005. Otimização da injeção cíclica de vapor em reservatórios de óleo pesado. Master Dissertation on Chemical Engineering - Programa de Pós-Graduação em Engenharia Química, Universidade Federal do Rio Grande do Norte, Natal, Brazil, 2005. 119 pp.

SANTOS NETO EV \& HAYES JM. 1999. Use of hydrogen and carbon stable isotopes characterizing oils from the Potiguar Basin (onshore), northeastern Brazil. American Association of Petroleum Geologists Bulletin, 83(3): 496-518.

TELES DRS, AZEVEDO AEG \& SANTOS CPL. 2010. Caracterização isotópica de águas de formação hipersalinas de um campo de petróleo da Bacia do Recôncavo, Brasil. Brazilian Journal of Geophysics, 28(2): 291-301.

TELES DRS, AZEVEDO AEG, COSTA AB, ZUCCHI MR \& FERREIRA AA. 2014. Physicochemical and isotopic characterization of formation waters from oil fields in the Sergipe Basin, Brazil. Brazilian Journal of Geophysics, 32(3): 531-538. 